\title{
Ectoparasite infestation and Vibrio alginolyticus bacterial infection in super-intensive ponds with high ammonia levels of Penaeus vannamei
}

\author{
Aprillia Deriyanti $^{1^{*}}$, Gunanti Mahasri ${ }^{2}$, Kismiyati $^{2}$ \\ ${ }^{1}$ Master Student of Fisheries Science, Faculty of Fisheries and Marine, Airlangga University, \\ Indonesia \\ ${ }^{2}$ Department of Management of Fish Health and Aquaculture, Faculty of Fisheries and \\ Marine, Airlangga University, Surabaya
}

\begin{abstract}
Disruption to fish and shrimp farming can be caused by poor water quality or invading pathogens. This study aims to determine the degree of ectoparasite infestation and Vibrio alginolyticus bacterial infection in super-intensive ponds. This study uses a survey method. Water and shrimp sampling was carried out at three stations and two sampling points. The study was conducted from January until February 2020. Water quality, parasite, and bacterial identification were measured at the Jepara Center for Brackish Water Cultivation Fisheries. This study showed that all samples were positively infested with Zoothamnium, Epistylis, and Vorticella parasites. The highest number of Vibrio bacteria was found at an average of $1.16 \times 10^{5}$ cells / mL. Based on Pearson correlation analysis, the relationship between the total number of bacteria and the ectoparasite intensity level in Pacific white shrimp has a value of 0.015 with an R-value $=0.828$. This indicates that the presence of high ectoparasite intensity. Water quality data also shows a very close relationship between the level of ectoparasite intensity and the stocking density of vannamei shrimp.
\end{abstract}

\section{Introduction}

Super-intensive vannamei shrimp cultivation uses feed in the range of $60-70 \%$ of the total operational costs with a feed conversion ratio of 1.3-1.6 and makes it organic waste [1]. The feed given is mostly utilized by vannamei shrimp through its digestion process and converted into energy and nutrients. At the same time, the rest of the feed will be wasted due to excretion in both dissolved and fecal form, which is wasted water bodies and undergoes a process of dissolution, sedimentation, mineralization, and dispersion [2].

Increasing pollutants in a water body can cause toxins to interfere with the life process and, after reaching certain levels, can be acute in fish and crustacean [3]. Nitrogen compounds produced by the leftover feed are generally in the form of ammonia, nitrite, and nitrate, which are toxic when the concentration exceeds the quality standard and can have a negative impact on fish cultivation [4]. The negative effect is caused by high ammonia

\footnotetext{
* Corresponding author: apriliaderiyanti18@gmail.com
} 
concentrations such as decreasing dissolved oxygen in water, stimulating the growth of aquatic plants, including microalgae, eutrophication, and causing toxicity to aquatic life that can cause death in fish cultured [5].

Disturbances in fish and shrimp farming can be caused by poor water quality, feed or pathogens invasion [7]. The quality of water and feed in shrimp culture is determined by the culture pattern applied during the invasion of the pathogen due to poor water quality in culture. One of the pathogens in shrimp is ectoparasites [8]. Furthermore, it is known that several ectoparasites from the protozoan class that often infest shrimp are Zoothamnium, Vorticella, and Epistylis [9].

The ectoparasites that are often found in vannamei shrimp are Zoothamnium sp., which mostly infest the entire body surface and gills of shrimp larvae [10]. Zoothamnium sp. Infects the shrimp raised in ponds with low oxygen content and poor water quality, heavily infested shrimp can die [11]. Epistylis sp. is another ectoparasite that infests the shrimp, mostly found in low dissolved oxygen conditions, clustered like threads that grow and attack shrimp body parts, causing stress, movement, and respiration disorders to death [12]. The ciliate class such as Vorticella sp. can normally live in good water quality, but the protozoa will increase in population in waters with low water quality [13]. Protozoan groups such as Zoothamnium, Epistylis, and Vorticella are usually found in stressed shrimp. They are affected by changes in water quality condition fluctuations, especially temperature, and maintenance containers that contain a lot of food residue, resulting in a buildup of organic matter, which will increase ammonia levels and cause a decrease in dissolved oxygen content [9].

Apart from parasites, bacteria are also one of the pathogens that often attack shrimp. Bacteria from the Vibrionaceae group are the main pathogens at the shrimp hatchery level [14]. Several Vibrio species that are frequently reported to cause vibriosis infection in shrimp include $V$. harveyi, $V$. parahaemolyticus, $V$. alginolyticus, $V$. aguillarum and $V$. vulnificus [15]. Vibriosis in penaeid shrimp is generally recognized as a secondary infection influenced by stress, environmental failures, and high numbers of potentially pathogenic bacteria in the environment [16].

Therefore, super-intensive cultivation with the amount of feed given can cause ammonia content in the waters. This high ammonia will cause the quality of the water to decrease and cause the shrimp to become pathogenic. This study aims to determine ectoparasite infestation and Vibrio alginolyticus bacterial infection in super-intensive ponds with high ammonia levels.

\section{Material and methods}

\subsection{Location and time}

Water and shrimp sampling were conducted at three stations and 2 point sampling each. Sampling point 1 and 2 in Pasuruan Regency, point 3 and 4 in Lamongan Regency, and the last point 5 and 6 in Tuban Regency, East Java. The research was conducted in JanuaryFebruary 2020. Water quality, parasite identification, and bacteria identification are conducted in the Brackishwater Aquaculture Center (BAC), Jepara, Central Java, Indonesia.

\subsection{Data collection}

Following the provisions [17], the sampling conducted for fish or shrimp health checks is $1 \%$ of the population. The degree of infestation in shrimp was measured by taking the total 
population of each location point was 5,000 , so that 50 vannamei shrimp were taken as samples at each point. From 6 points, 300 vannamei shrimp were obtained, then grouped based on the degree of ectoparasite infestation.

Total Plate Count (TPC) measurements were carried out by isolating Vibrio bacteria at 6 shrimp pond locations. Sampling was performed six times for each location point. Vibrio isolation on water samples was diluted until the dilution factor reached $10^{-4}$. Each dilution factor was planted by pouring a plate on Thiosulfate Citrate Bile Salt Sucrose Agar (TCBS) media. Incubation was carried out for 24 hours at a temperature of $30{ }^{\circ} \mathrm{C}$. The total number of Vibrio bacteria was calculated for each sample. Pure isolates obtained from the isolation results were stored on slanted Tryptic soy agar (TSA) media containing 5\% $\mathrm{NaCl}$ [14].

An incidental sampling technique is used to collect water quality. The water sample was then taken at $1.5 \mathrm{~L}$ to take $30 \mathrm{~cm}$ from the bottom of the water. Water samples from each station were then put into bottles and stored in a box filled with ice. The function of giving ice is to prevent biological and chemical changes in the sample, then the box is tightly closed and taken to the BAC laboratory for analysis.

\subsection{Data analysis}

\subsubsection{Ectoparasite identification}

\section{a. Examination of samples and calculation of the prevalence of ectoparasites infesting vannamei shrimp}

The vannamei shrimp log samples were put into the aquarium as a temporary place. The vannamei shrimp logs examined were placed on an object glass and then observed using a microscope with 100x and 400x. Ectoparasite examination was carried out on living vannamei shrimp. The parts examined included the entire body surface, gills, legs, tail, eyes, and carapace [18]. Then the prevalence is calculated.

\section{b. Ectoparasite staining}

After obtaining the protozoa ectoparasites, then staining was carried out. Namely, the examined preparations were dried and then fixed using methanol for 5 minutes, after that, stained with Giemsa 10\% for 15-20 minutes. Then rinsed with clean water and dried [19].

\section{c. Ectoparasite identification}

The ectoparasites found were identified based on the specific characteristics found. Zoothamnium, Vorticella, and Epistylis identification based on Kabata (1985) [20].

\subsubsection{Bacteria identification}

\section{a. Postulat Koch Test}

The test used Vibrio sp. isolate, which was the most dominant isolated from pond water. Vibrio sp. isolates for testing were cultured on Alkaline Peptone Water (APW) media for 24 hours at $\pm 30^{\circ} \mathrm{C}$. The harvested bacteria were centrifuged at $5000 \mathrm{rpm}$ for 5 minutes. The pellets were resuspended in $10 \mathrm{~mL} 0.9 \%(\mathrm{w} / \mathrm{v}) \mathrm{NaCl}$. Cultures were standardized to the $5 \% \mathrm{McF}$ arland standard with an estimated colony density of $1 \times 10^{7}-10^{8} \mathrm{CFU} / \mathrm{mL}$. The calculation of the density of the culture colonies was then performed using the total plate count method. The bacterial suspension was inoculated in each experimental container as much as $5 \mathrm{~mL}$ at a concentration of $10^{7}-10^{8} \mathrm{CFU} / \mathrm{mL}$. 
b. Total Plate Count Vibrio sp. with the following calculations:

$$
\Sigma \text { Bacteria }=\mathrm{V} \times \mathrm{n} \times 1 / \mathrm{f}
$$

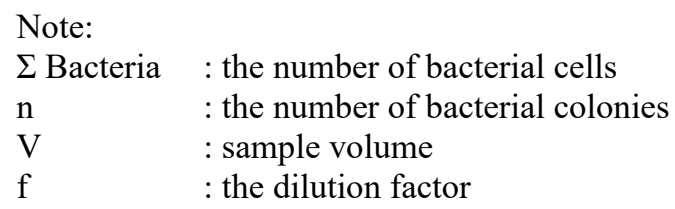

\section{c. Identification of the bacteria causing vibriosis}

The pathogenic bacteria causing vibriosis were characterized microscopically, Gram stain $t$, serology, and biochemical test. Biochemical tests are carried out using BBL Crystal тм Identification Systems KIT.

\subsubsection{Correlation test}

\section{a. Correlation coefficient test}

In finding the magnitude of the relationship and contribution of two or more independent variables $(\mathrm{X})$ or more simultaneously (together) with the dependent variable $(\mathrm{Y})$, multiple correlation analysis is used. Multiple correlation analysis is also used to measure the index or number of the closeness of the relationship between 3 or more variables.

The multiple correlation coefficient is formulated:

$$
\mathrm{Rx}_{1}, \mathrm{x}_{2}, \ldots \mathrm{x}_{i} \mathrm{y}=\frac{\sqrt{\mathrm{b}_{1} \sum \mathrm{x}_{1}+\mathrm{b}_{2} \sum \mathrm{x}_{2} \mathrm{y}+\mathrm{y}}}{\sum \mathrm{y}}
$$

Note:

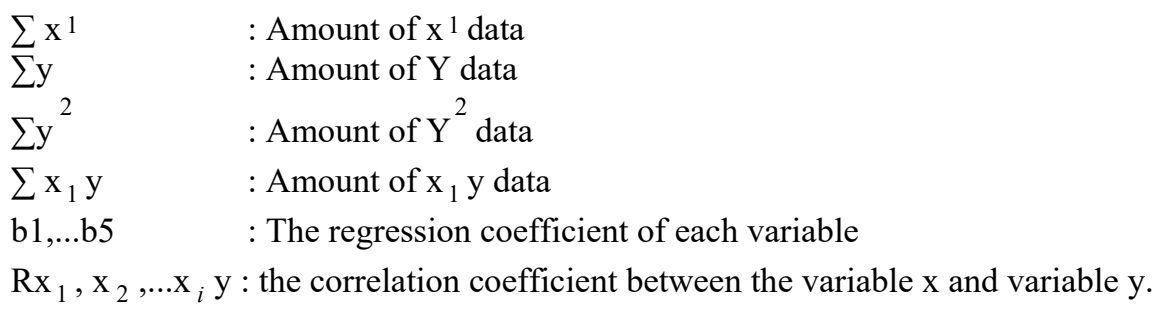

This multiple correlation test was used SPSS (Statistical Product and Service Solutions). 


\section{Results and discussion}

\subsection{Results}

\subsubsection{Ectoparasite identification}

The results of ectoparasite identification scattered in the three districts (Pasuruan, Lamongan, and Tuban Regency) can be seen in Table 1.

Table 1. Ectoparasite identification.

\begin{tabular}{|l|l|c|l|c|c|}
\hline No. & \multicolumn{1}{|c|}{ Ponds Location } & $\begin{array}{c}\text { Number of } \\
\text { shrimp }\end{array}$ & Ectoparasites & $\begin{array}{c}\text { Parasite } \\
\text { Intensity }\end{array}$ & $\begin{array}{c}\text { Degree of } \\
\text { Parasite } \\
\text { infestation }\end{array}$ \\
\hline 1. & Ponds 1 (Pasuruan) & 50 & $\begin{array}{l}\text { Positive: Zoothamnium, } \\
\text { Epistylis, and Vorticella }\end{array}$ & 39 & Moderate \\
\hline 2. & Ponds 2 (Pasuruan) & 50 & $\begin{array}{l}\text { Positive: Zoothamnium, } \\
\text { Epistylis, and Vorticella }\end{array}$ & 6 & Mild \\
\hline 3, & Ponds 3 (Lamongan) & 50 & $\begin{array}{l}\text { Positive: Zoothamnium, } \\
\text { Epistylis, and Vorticella }\end{array}$ & 27 & Moderate \\
\hline 4. & Ponds 4 (Lamongan) & 50 & $\begin{array}{l}\text { Positive: Zoothamnium, } \\
\text { Epistylis, and Vorticella }\end{array}$ & 76 & Severe \\
\hline 5. & Ponds 5 (Tuban) & 50 & $\begin{array}{l}\text { Positive: Zoothamnium, } \\
\text { Epistylis, and Vorticella }\end{array}$ & 8 & Mild \\
\hline 6. & Ponds 6 (Tuban) & 50 & $\begin{array}{l}\text { Positive: Zoothamnium, } \\
\text { Epistylis, and Vorticella }\end{array}$ & 55 & Severe \\
\hline
\end{tabular}

Of 300 samples of vannamei shrimp examined from 3 locations and two samples from different locations, all of them were positively infested with parasite Zoothamnium, Epistylis, and Vorticella. The prevalence rate of ectoparasite in vannamei shrimp at each sample location shows a different intensity level. The highest ectoparasite intensity was at a pond sample point 4 with a value of 76 with the degree of severe infestation. In contrast, the results of the TPC examination of Vibrio bacteria are shown in Table 2.

Table 2. Bacteria identification.

\begin{tabular}{|c|l|c|l|l|c|}
\hline No. & \multicolumn{1}{|c|}{ Ponds Location } & $\begin{array}{c}\text { Number } \\
\text { of shrimp }\end{array}$ & \multicolumn{1}{|c|}{ Bacteria identification } & $\begin{array}{c}\text { TPC } \\
(\text { cell/ml) }\end{array}$ & Note \\
\hline 1. & Ponds 1 (Pasuruan) & 6 & Positive V. alginolyticus & $1,3 \times 10^{4}$ & Normal \\
\hline 2. & Ponds 2 (Pasuruan) & 6 & Negative & $0,38 \times 10^{3}$ & Normal \\
\hline 3. & Ponds 3 (Lamongan) & 6 & Positive $V$. alginolyticus & $1,3 \times 10^{4}$ & Normal \\
\hline 4. & Ponds 4 (Lamongan) & 6 & Positive $V$. alginolyticus & $1,16 \times 10^{5}$ & Normal \\
\hline 5. & Ponds 5 (Tuban) & 6 & Negative & $0,3 \times 10^{3}$ & Normal \\
\hline 6. & Ponds 6 (Tuban) & 6 & Positive V. alginolyticus & $1,16 \times 10^{5}$ & Normal \\
\hline
\end{tabular}

Calculation of total Vibrio bacteria from 3 locations (Pasuruan, Lamongan, and Tuban) and two samples on average had an abundance of Vibrio of zero to $1 \times 10^{4}$ cells $/ \mathrm{ml}$. The highest Vibrio bacteria was found in pond 4 (Lamongan) with an average of $1.16 \times 10^{5}$ cells $/ \mathrm{ml}$ and identified positive $V$. alginolyticus, $V$. parahaemolicus, and EHP (Enterocytozoon hepatopanaei). At the same time, the negative samples were in pond 2 (Pasuruan) and pond 5 (Tuban).

Table 3. Pearson Correlation Test.

\begin{tabular}{|c|c|c|}
\hline Parameter & Bacteria TPC & R Value \\
\hline Intensity level of ectoparasites & $0.015^{*}$ & 0.828 \\
\hline
\end{tabular}


Note:

** Correlation is significant at the 0.01 level

* Correlation is significant at the 0.05 level

Based on a statistical analysis of Pearson correlation in Table 3, the relationship between the total number of bacteria and the intensity level of ectoparasites in white vannamei shrimp has a value of $0.015^{*}$ with an R-value of 0.828 . This means a strong relationship of $82 \%$ between the total number of infecting bacteria and the intensity level of ectoparasites in the vannamei shrimp studied.

The results of water quality measurements at 6 location points at three stations can be seen in Table 4.

Table 4. Water quality in various ponds.

\begin{tabular}{|l|c|c|c|c|c|c|c|}
\hline \multicolumn{1}{|c|}{ Ponds } & $\begin{array}{c}\mathrm{DO} \\
(\mathrm{mg} / \mathrm{L})\end{array}$ & $\begin{array}{c}\text { Temperature } \\
\left({ }^{\circ} \mathrm{C}\right)\end{array}$ & $\mathrm{pH}$ & $\begin{array}{c}\text { Salinity } \\
(\mathrm{ppt})\end{array}$ & $\begin{array}{c}\text { Nitrate } \\
(\mathrm{mg} / \mathrm{L})\end{array}$ & $\begin{array}{c}\text { Nitrite } \\
(\mathrm{mg} / \mathrm{L})\end{array}$ & $\begin{array}{c}\text { Ammonia } \\
(\mathrm{mg} / \mathrm{L})\end{array}$ \\
\hline $\begin{array}{l}\text { Ponds 1 } \\
\text { (Pasuruan) }\end{array}$ & 4,2 & 29 & 7,5 & 17 & 15 & 0,3 & 0,5 \\
\hline $\begin{array}{l}\text { Ponds 2 } \\
\text { (Pasuruan) }\end{array}$ & 4,1 & 29 & 7.2 & 17 & 10 & 0,5 & 0,5 \\
\hline $\begin{array}{l}\text { Ponds 3 } \\
\text { (Lamongan) }\end{array}$ & 4,2 & 28,5 & 7 & 17 & 15 & 0,2 & 0,5 \\
\hline $\begin{array}{l}\text { Ponds 4 } \\
\text { (Lamongan) }\end{array}$ & 3,8 & 29 & 6,8 & 19 & 20 & 1,0 & 1,2 \\
\hline $\begin{array}{l}\text { Ponds 5 } \\
\text { (Tuban) }\end{array}$ & 4.0 & 28,5 & 7,5 & 17 & 15 & 0,5 & 0,5 \\
\hline $\begin{array}{l}\text { Ponds 6 } \\
\text { (Tuban) }\end{array}$ & 3.7 & 29 & 6,8 & 18 & 20 & 1,2 & 1.0 \\
\hline
\end{tabular}

The relationship between some water quality and the total plate count of bacteria and the level of ectoparasite intensity in vannamei shrimp is a Pearson correlation in Table 5.

Table 5. Pearson Correlation Test.

\begin{tabular}{|l|c|c|}
\hline \multirow{2}{*}{ Water Quality Parameter } & \multicolumn{2}{|c|}{ Pearson Correlation Value (R) } \\
\cline { 2 - 3 } & Bacteria TPC & Ectoparasite Intensity \\
\hline DO & 0.373 & 0.354 \\
\hline Temperature & 0.276 & 0.414 \\
\hline $\mathrm{pH}$ & $0.039^{*}$ & 0.165 \\
\hline Salinity & $0.038^{*}$ & $0.034^{*}$ \\
\hline Nitrate & $0.043^{*}$ & $0.008^{* *}$ \\
\hline Nitrite & $0.338^{*}$ & 0.354 \\
\hline Ammonia & $0.038^{*}$ & $0.034^{*}$ \\
\hline
\end{tabular}

Note:

** Correlation is significant at the 0.01 level

* Correlation is significant at the 0.05 level

Based on the statistical analysis of correlation, it was found that there was a close relationship between several water quality parameters with bacterial TPC and ectoparasite intensity. $\mathrm{pH}$, the salinity of nitrate, and ammonia have a strong correlation with bacterial TPC. Salinity and ammonia also have a close relationship with the higher intensity of ectoparasites. Meanwhile, nitrate has a very close relationship with the presence of ectoparasite intensity with a value of $\mathrm{R}=0.008$. 


\subsection{Discussion}

All 300 samples of vannamei shrimp were examined from 3 locations and two samples from different locations were positively infested with parasite Zoothamnium, Epistylis, and Vorticella. The prevalence rate of ectoparasite in vannamei shrimp at each sample location shows a different intensity level. All shrimp samples can be infested with Zoothamnium, Epistylis, and Vorticella because these parasites have a definitive host in crustaceans. However, Epistylis and Vorticella are found in freshwater fish farming but can sometimes attack crustaceans such as vannamei shrimp. In addition, these parasites live in colonies and reproduce more rapidly if contributing factors such as water quality become worse [22]. Protozoan parasites are generally in conditions where the shrimp are stressed and are found by changes in fluctuations in water quality conditions, especially temperature, and treatments that contain a lot of leftover feed. Consequently, there is an accumulation of organic matter which will increase the ammonia level so that the dissolved oxygen content in the air will decrease. The abundance of protozoan ectoparasites varies greatly depending on the physicochemical conditions of different air bodies. As stated, the highly nutrient-rich waters commonly found in situations tend to favor the proliferation of ectoparasite organisms ${ }^{[8]}$.

The highest Vibrio bacteria were found in pond 4 (Lamongan) with an average of $1.16 \mathrm{x}$ $10^{5}$ cells $/ \mathrm{ml}$ and identified positive $V$. alginolyticus, $V$. parahaemolicus, EHP (Enterocytozoon hepatopanaei). While the negative samples were in pond 2 (Pasuruan) and pond 5 (Tuban). Vibrio disease is a secondary infection due to opportunism pathogenic. The main causes can include other infectious agents, diminishing value of environmental water quality, nutritional deficiencies, and management and stress-induced [23]. Vibrio bacteria have the potential to develop as a pathogen opportunistic [24]. It is according [25] This can occur when there is an increase in organic material from the feed and feces, which encourages the microflora to develop into opportunistic pathogens.

Based on a statistical analysis of Pearson correlation in Table 3, the relationship between the total number of bacteria and the intensity level of ectoparasites in white vannamei shrimp has a value of $0.015^{*}$ with an $\mathrm{R}$-value of 0.828 . This means a strong relationship of $82 \%$ between the total number of infecting bacteria and the intensity level of ectoparasites in the vannamei shrimp studied. This is following the opinion [26] that the presence of high intensity of ectoparasites will be used by other pathogens such as bacteria to enter the shrimp body to reduce the level of immunity and body resistance.

There is a very close correlation between the level of ectoparasite intensity and stocking density. The higher the stocking density, the higher the prevalence rate of ectoparasite infesting vannamei shrimp [10]. The results showed that the ponds with high stocking densities indicated ectoparasite infestations. At high stocking density, it causes an increase in organic matter in the waters from metabolic waste. If this organic material cannot be broken down into inorganic material by microorganisms, it will cause ammonia to appear, which can interfere with shrimp growth. This can be seen in the water quality data and correlation Pearson in Table 4 and Table 5, which shows a strong correlation between ammonia and the intensity of ectoparasites and bacterial infections. This is supported by the opinion of [9] which states that high stocking densities will increase the content of organic matter due to the accumulation of leftover feed. If the process of changing organic matter is disrupted, decay will occur, resulting in a decrease in $\mathrm{pH}$ and dissolved oxygen. This can stress the shrimp. As a result, direct contact between shrimp and parasites is high enough so that the parasites can easily infest the vannamei shrimp logs, and the transmission of parasite infestations is quite fast, and disease attacks cannot be avoided. 


\section{Conclusion}

All ponds in Pasuruan, Lamongan, and Tuban were infected by ectoparasite and vibriosis. There is a very close relationship between the stocking density of shrimp and the high ammonia on ectoparasite intensity and vibrio bacterial infection. The higher stocking density and ammonia caused an increasing ectoparasite intensity and vibriosis infection in vannamei shrimp.

\section{References}

1. N.A. Rangka, Gunarto, J. Ilm. Perikan. Kelaut. 4, 141-149 (2012)

2. R. Syah, Makmur, M.C. Undu, J. Ris. Akuakultur 9, 439-448 (2014)

3. F.B. Eddy, J. Fish Biol. 67, 1495-1513 (2005)

4. H. Kroupova, J. Machova, Z. Svobodova, Vet. Med. 50, 461-471 (2005)

5. M. Radhi, Zulfikri, Toxicity of feed waste (ammnoniac) on health fish (2019)

6. S.G. Fekete, R.O. Kellems, Vet. Med. 52, 131-143 (2007)

7. J. Selvin, A.S. Ninawe, R. Meenatchi, G.S. Kiran, Nutr. Acuícola Investig. y Desarro. 102-141 (2015)

8. U. Hafidloh, P.D.W. Sari, IOP Conf. Ser. Earth Environ. Sci. 236, 0-3 (2019)

9. G. Mahasri, A. Heryamin, Kismiyati, J. Aquac. Fish Heal. 5, 7-13 (2016)

10. G. Mahasri, H. Suprapto, A. Farras, J. Ilm. Perikan. Kelaut. 9, 118-126 (2017)

11. S. Kakoolaki, M. Afsharnasab, Iran. J. Aquat. Anim. Heal. 2, 17-23 (2016)

12. S. Huseyin, B.J Selcuk, Anim. Vet. Adv. 4, 789-793 (2005)

13. T. Rohman, Psikol. Perkemb. 5, 1-224 (2019)

14. N.W.D. Bintari, R. Kawur, A.A.G.R. Dalem, J. Biol. 20, 53-58 (2012)

15. R. Novriadi, Omni-Akuatika 12, 1-12 (2016)

16. C.H. Liu, W.Cheng, J.P. Hsu, J.C. Chen, Dis. Aquat. Organ. 61, 169-174 (2004)

17. BSN, Sampling Method of fish and shrimp seeds (in Bahasa Indonesia) (BSN, Jakarta, 2000)

18. G. Saptiani, C.A Pebrianto, Agustina, E.H. Hardi, F. Ardhani, Biodivers. 18, 666-670 (2017)

19. E.R Cruz-Lacierda, Parasitic diseases and Pests. In G.D. Lio-Po, C.R. Lavilla. E.R. Cruz-Lacierda (Eds.), health management in aquaculture (Aquaculture Department Southeast Asian Fisheries Development Center, Tigbauan, 2001)

20. A.W. Pike, J. Trop. Ecol. 1, 110 (1985)

21. E.I. Obilor, E.C. Amadi, Int. J. Innov. Math. Stat. Energy Policies 6, 11-23 (2018)

22. G. Mahasri, T. Hidayat, Sudarno, IOP Conf. Ser. Earth Environ. Sci. 236, 0-6 (2019)

23. S.A. Mastan, S.K.A Begum, Int. J. Appl. Sci. Biotechnol. 4, 217-222 (2016)

24. M.L. Kent, Int. J. Parasitol, 30, 321-326 (2000)

25. Otta S.K, I. Karunasagar, I. Karunasagar, J. Appl. Ichthyol. 17, 59-63 (2001)

26. E. Wulandari, E. Herawati, D. Arfiati, J. Fish. Mar. Res. 1, 10-14 (2012) 